\title{
Climate Change Impacts on Nutrient and Sediment Loads in a Midwestern Agricultural Watershed
}

\author{
S. T. Y. Tong ${ }^{1 *}$, A. J. Liu ${ }^{1}$ and J. A. Goodrich ${ }^{2}$ \\ ${ }^{1}$ Department of Geography, University of Cincinnati, Cincinnati, OH 45221-0131, USA \\ ${ }^{2}$ Water Quality Management Branch, National Risk Management Research Laboratory, \\ US Environmental Protection Agency, Cincinnati, OH 45268-0690, USA
}

\begin{abstract}
The objective of this study is to examine the water quality impacts of climate change in a predominantly agricultural, but rapidly urbanizing, watershed in the American Midwest, the Little Miami River (LMR) watershed. Future climatic conditions were simulated based on various climatic scenarios. The Soil and Water Assessment Tool (SWAT), a long-term, continuous, watershed-scale hydrologic model, was used to predict the potential changes in flow, total nitrogen, total phosphorus, and sediment loads. Results indicate that daily flow can vary by $35 \%$. Besides, the LMR watershed has an overabundance of phosphorus. It is likely that eutrophication will be exacerbated in future climatic conditions; hence strategies to control non-point source pollution by only reducing nitrogen may not be adequate. Moreover, the hydrological impacts of future climate change will be large enough to warrant modifications in our response and utilization of water resources.
\end{abstract}

Keywords: BASINS, climate change, geographic information systems, non-point source pollution, surface water hydrology, watershed management, water resources planning

\section{Introduction}

Increases in greenhouse gases can cause significant changes in climate and weather patterns. The Intergovernmental Panel on Climate Change (IPCC) has stated that a rise of the mean surface temperature from 1 to $6{ }^{\circ} \mathrm{C}$ can be felt in North America in the next century (IPCC, 2001,2004). For the state of Ohio, projections made by the IPCC and the United Kingdom Hadley Centre's climate model (HadCM2) predict that by 2100 , temperatures can increase by 2 to $4{ }^{\circ} \mathrm{C}$ and annual average precipitation can change by -20 to $20 \%$ (Karl et al., 1996; USEPA, 1998). These changes can impact many important aspects of the regional economy in the Ohio River Basin, such as agriculture, forestry, and water resources. According to the U.S. National Assessment Synthesis Team of the U.S. Global Change Research Program, USGCRP, “... natural ecosystems, which are our life support system in many important ways, appear to be the most vulnerable to the harmful effects of climate change ..." (USGCRP, 2000).

As our life is dependent on the quality and quantity of the water resources, it is important to assess the potential hydrologic impacts of future climate change. Several studies conducted in the American Southeast (Bingner et al., 1989; Cooter et al., 1990), the Central United States (Sophocleous et al., 1999; Nash and Gleick, 1991; Thompson, 1992; Henratty and Stefan, 1998; Donner and Kucharik, 2003), the Northeast and MidAtlantic Region (Cho et al., 1995; Crawford and Jennings,

\footnotetext{
* Corresponding author: susanna.tong@uc.edu
}

1989; Najiar, 1999), and in the American West (Flaschka et al., 1987; Gleick, 1987; Lettenmaier and Gan, 1990; Dettinger et al., 2004) have concluded that climate variability will have significant impacts on the hydrologic fluxes, nutrient export, and the overall water quality in the riverine systems. Further changes in climate and in the frequency of extreme climatic events will aggravate eutrophication and hypoxia (Justic et al., 2003). It is therefore prudent to have a better understanding of the causal relationships between climate change, riverine sediment and nutrient fluxes, and eutrophication. The present study uses results from recent GCMs as future climatic conditions to simulate the water quality impacts of climate change in a predominantly agricultural watershed in southwestern Ohio, the LMR watershed. It is part of a larger U.S. Environmental Protection Agency (USEPA) program investigating how cities and local communities can implement adaptation and mitigation strategies to reduce the adverse hydrologic impacts of climate change.

The LMR watershed was chosen in this study because it has been monitored by the U.S. Geological Survey (USGS) since 1920. Continuous records of stream flow are available for many areas in the river. There are also historical climate, land use, permitted point source discharge, and water quality data. Moreover, LMR contains some of the most diverse riverine habitats in the region, and is home to approximately 84 fish species (U.S. Forest Service and National Park Service, 1999). It is one of the state's remaining high-quality streams. The Ohio Environmental Protection Agency (Ohio EPA) has listed the LMR as the largest exceptional warm water habitat 
stream in the state - only $10 \%$ of the total streams in the state are given this designation (Ohio EPA, 1995). In addition, the Ohio Department of Natural Resources (ODNR) has designated the river as a state and national scenic river to protect it for future generations.

However, the LMR watershed has been experiencing extensive urbanization in recent years. This may be because some residents of the two major urban centers (Cincinnati and Dayton) have been relocating from the city centers to suburbs. Census data show a steady increase of population in counties that border Cincinnati and Dayton Metropolitan Areas since 1940's: Clermont County (80\%), Warren County (77\%), Greene County (75\%), and Butler Country (62\%). Such migration pattern is usually accompanied by the conversion of agricultural and forested lands to residential and commercial areas, resulting in development that can adversely affect water quality and aquatic ecosystems. Land-use change, for example, from forests to impervious urban areas can increase the instream nutrient levels (Liu et al., 2000; Tong and Chen, 2002), which in turn can lead to eutrophication and hypoxia (Burkart and James, 1999). This is because elevated levels of nitrogen and phosphorus have the potential to affect oxygen and food supplies for aquatic communities through algae bloom. When the algae die and decompose, they consume oxygen in the water. Severe oxygen shortages may result in fish kills, reducing species abundance. Moreover, streams clogged with weeds are undesirable for recreational uses, such as swimming and boating. Decaying algae also cause unpleasant odor problems (Perry, 1989).

There are additional indications that the LMR is a system under stress. The Ohio EPA has discovered high levels of fish anomalies and changes in fish composition, which may be attributed to nutrient enrichment. The Ohio EPA feels that a significant factor contributing to the problem is the level of phosphorus in the river. In a water quality study of the LMR basin in 1998, the Ohio EPA found that "virtually all total phosphorus concentrations $(96 \%)$ were greater than the minimum detection limit of $0.05 \mathrm{mg} / \mathrm{L}$ with a median concentration of $0.34 \mathrm{mg} / \mathrm{L}$ for all values recorded in the main stem" (Ohio EPA, 2000).

In the main stem and tributaries of LMR, there are combined sewer overflows (CSOs). During low stream flows, discharges from wastewater plants can comprise 30 to $70 \%$ of total stream flow. Undoubtedly, as urbanization continues, there will be an increase in wastewater and CSOs, which may further strain conditions in the LMR. The likelihood of climate change poses an additional threat to the water quality of the LMR watershed. For these reasons, it is of paramount importance to investigate the plausible future hydrologic conditions.

\section{Methodology}

\subsection{Study Site}

Located in southwest Ohio, the LMR watershed (Figure 1) has a cool temperate climate. The average annual precipitation in the watershed ranges from 89 to $109 \mathrm{~cm}$; about one-third of the precipitation becomes surface runoff. Average annual air temperature ranges from $10{ }^{\circ} \mathrm{C}$ in the north to $13{ }^{\circ} \mathrm{C}$ in the south. Average snowfall in the watershed is 50 to $76 \mathrm{~cm}$ per year (Debrewer et al., 2000).

The watershed is in the Till Plains section of the Central Lowlands Physiographic Province. For most of its length, the LMR flows atop a buried valley aquifer composed of highly permeable sands and gravel from past glacial events. Along its course, the LMR drops from an elevation of 347 to $137 \mathrm{~m}$ with an average gradient of $1.2 \mathrm{~m}$ per $\mathrm{km}$. The main stem of the LMR is $171 \mathrm{~km}$ long, while its tributaries span over 4108 $\mathrm{km}$ in the watershed, covering $4498 \mathrm{sq} \mathrm{km}$ and eleven counties in southwestern Ohio (ODNR, 1964).

The topography of the watershed has been influenced by glaciation, which has left distinctive landforms and thick deposits of silt, sand, and gravel. Glaciation and subsequent erosion has produced a flat to gently rolling land surface that is cut by steep-walled river valleys of low to moderate relief. The northern portion of the watershed is within the Eastern Corn Belt Plains ecoregion, which is characterized by level to gently sloping land, and relatively low gradient streams, and areas of fertile soil. In the southernmost areas, the glacial cover was relatively thin and the erosion of the less resistant shales has produced a more dissected, hilly terrain of higher stream density (USGS, 2000a).

The principal aquifer in the watershed is a complex, buried-valley system. This aquifer has been designated a solesource aquifer by the USEPA and is the principal source of drinking water for 1.6 million people. The aquifer is found in bedrock valleys incised into uplifted Silurian and Ordovician bedrock by a tributary of the preglacial Teays River drainage system. These valleys were largely in-filled by sediments deposited by advancing glaciers (tills) or filled in by coarsegrained sediments deposited by glacial meltwaters (outwash). In many valley sections, the aquifers are shielded by an overlying aquiclude composed of slack-water lacustrine clay deposits. Depth to water in most parts of the aquifer is less than 6 $\mathrm{m}$. In the northern part of the watershed, Silurian limestones and dolomites form a carbonate bedrock aquifer that is used for domestic and small industrial supply. In the southern part of the watershed, the shale-rich Ordovician bedrock complex is poorly permeable and is used for domestic water supply only where other sources of water are not available (Lerch et al., 1975).

In 1995, an estimated 155 million L/day of water was withdrawn from streams and aquifers in the LMR watershed. Of this, approximately $25 \%$ was withdrawn from surfacewater bodies, whereas the remaining $75 \%$ was derived from ground-water sources. Most of this ground water is pumped from the buried-valley aquifer underlying stream valleys associated with the LMR (Ohio EPA, 2000).

\subsection{Climate-Change Scenarios}

In this study, we adopted various climate change scenarios for the analysis. Many scientists prefer to use a range of 


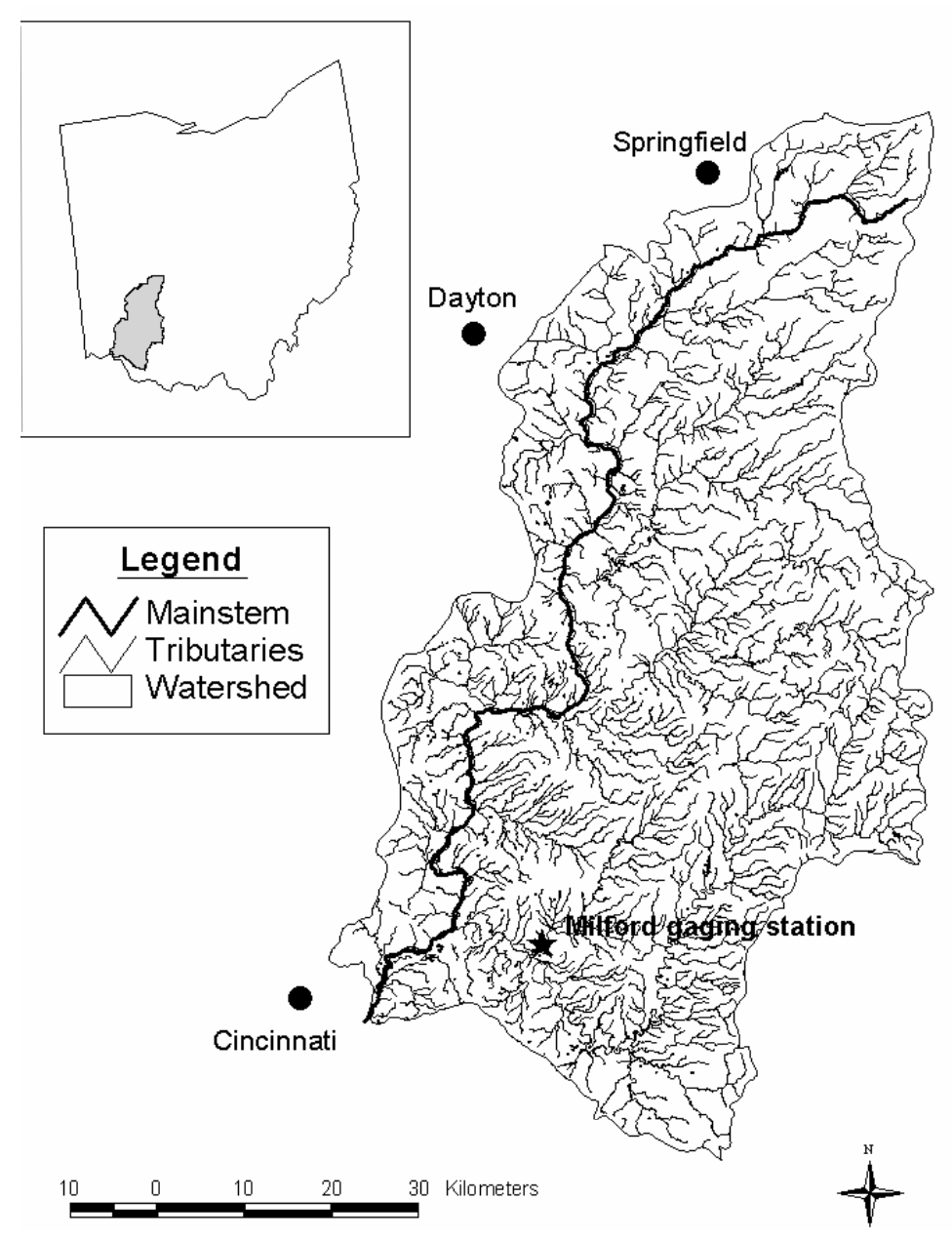

Figure 1. Little Miami River watershed.

reliable climate scenarios in their hydrologic modeling (see for example the work of Dagnachew et al., 2003). We used this approach because the intent of this study was not to accurately predict our future climatic condition; instead, its goal was to assess the likely hydrologic conditions in times of global climate change. These scenarios therefore do not offer a prediction on what the future climate and hydrology will be, rather, they show the range of conditions that are possible, and the range of impacts resulting from these conditions; as such they can act as guidelines to help decision makers to develop adaptive and flexible solutions, which will work in a variety of situations (Karl, 1992; USGCRP, 2000).

We based our climate change scenarios on the projected results from IPCC and the United Kingdom Hadley Centre's climate models. Both of these models are highly regarded for their accuracy (see for example, Chang et al., 2002; Bonsal et al., 2003). They predicted that by 2100 , temperatures in Ohio could increase by 2 to $4{ }^{\circ} \mathrm{C}$ and precipitation could change by -20 to $+20 \%$ (Karl et al., 1996; USEPA, 1998).

In this study, five hypothetical climate change scenarios were derived. The base case scenario was derived from avera- ging the daily temperature and precipitation values for the last fifty years (from 1945 to 1995). This scenario represented the current temperature and precipitation conditions. In addition to the base case scenario, there were two wet scenarios and two dry scenarios. The "wet" scenario was depicted by a $4{ }^{\circ} \mathrm{C}$ increase in temperature and a $20 \%$ increase in precipitation; whereas the "wettest" scenario by a $2{ }^{\circ} \mathrm{C}$ increase in temperature and a $20 \%$ increase in precipitation. The "dry" scenario was depicted by a $2{ }^{\circ} \mathrm{C}$ increase in temperature and a $20 \%$ decrease in precipitation, and the "driest" scenario by a $4{ }^{\circ} \mathrm{C}$ increase in temperature and a $20 \%$ decrease in precipitation (Table 1).

\subsection{Calculation of Runoff and Non-Point Source Pollution}

In order to accurately portray the surface runoff and water quality conditions under a future climate scenario, an appropriate hydrologic model must be chosen. Hydrologic and water quality models are tools for simulating the movement of precipitation and pollutants from the ground surface through networks, storage treatment units, and finally to receiving waters. Both single-event and continuous simulations may be 
performed on watersheds having storm sewers and natural drainage, for prediction of flows, stages, and pollutant concentrations.

Table 1. Hypothetical Future Climate Scenarios

\begin{tabular}{ll}
\hline Scenario & Changes in Temperature/Precipitation \\
\hline Base Case & No Changes \\
Wettest & +2 Degrees Celsius \\
& $+20 \%$ Precipitation \\
Wet & +4 Degrees Celsius \\
& $+20 \%$ Precipitation \\
Dry & +2 Degrees Celsius \\
& $-20 \%$ Precipitation \\
Driest & +4 Degrees Celsius \\
& $-20 \%$ Precipitation \\
\hline
\end{tabular}

A review of literature have shown that many watershed hydrologic and water quality models, for example, HSPF (Bicknell et al., 1997), LTHIA (Bhadhuri et al., 1997), SWAT (Srinivasam et al., 1993; Arnold et al., 1994), INCA (Whitehead et al., 1998), AGNPS (Young et al., 1995), and HYDRA (Coe, 1998; Donner et al., 2002), have been adopted to assess the hydrologic effects of anthropogenic activities, benchmark the current hydrologic conditions, and determine the total maximum daily load (TMDL). These models differ in their methods, ease of use, degree of complexity and flexibility, level of spatial resolution, data and calibration requirements, and simulation accuracy. Some of them are deterministic models. Others are based on export-coefficient approaches (for example, Johnes and Heathwaite, 1997) or on statistical empirical or quasi-empirical studies (such as those by Howarth et al., 1996 and Caraco and Cole, 1999).

In this study, SWAT was chosen to simulate the climatic and hydrologic conditions in the LMR watershed because it is a physically based, watershed-scale model developed specifically to model the long-term impacts on sediment, water, and chemical and nutrient yields (i.e., non-point source pollution) in large complex ungauged watersheds with varying soil, land use, and management conditions over time. The model has been widely used by USEPA, U.S. Department of Agriculture (USDA), Natural Resources Conservation Services (NRCS), as well as National Oceanic and Atmospheric Administration (NOAA), and applied in many watersheds in the United States and Europe (Alexander et al., 2001; Arnold and Fohrer, 2005). Studies from Cho et al. (1995), Bingner et al. (1997), Peterson and Hamlett (1998), Hanratty and Stefan (1998), Ranjan and Wurbs (2002), Grizzetti et al. (2003), Tripathi et al. (2005), Chaplot et al. (2004), Romanowicz et al. (2005), and others have demonstrated that SWAT is a versatile and computationally efficient model and it can accurately simulate the effects of changes in climate, land-use, and management practices. The advantages of using SWAT are as follows: It enables researchers to study long-term impacts. The model requires minimal input information about weather, soil properties, topography, vegetation, and land management practices occurring within the watershed. It simulates a large number of different physical processes, such as evapotranspiration, lateral subsurface flow, return-flow from groundwater, surface runoff, nutrient cycling, erosion, and sediment yield. In addition, it also considers many stream processes, including channel flood routing, channel sediment routing, and nutrient and pesticide routing and transformation. Hence, it provides a much better representation of the natural hydrologic system. Furthermore, SWAT has the ability to partition a watershed into a number of sub-watersheds and hydrologic response units (HRUs). This can be useful when different areas of the watershed are dominated by land uses or soils different enough in hydrology to impact the rainfall-runoff process. Besides, SWAT is well documented. It is transparent and the source code can be downloaded from the web at no cost. SWAT version 2000 has a GIS-interface with GRASS and ArcView (Jayakrishnan et al., 2005). It has already been incorporated into the USEPA's Better Assessment Science Integrating Point and Non-point Sources (BASINS) package through a SWAT Extension Interface. BASINS is a GIS ArcView-based multipurpose environmental analysis system for watershed and water quality studies. The newest version 3.1 is free to the public and can be downloaded from the USEPA's web site. The system contains much GIS data and spatial coverages, as well as many utilities for pre-processing (for example, watershed delineation, model input generation) and tools for assessment (as an example, data mining) and post-processing (such as, displaying graphical and tabular results and interpreting outputs). This saves considerable time and money in assembling the required spatial data, creating the necessary input files, and examining the simulation outputs. Due to these reasons, it is very convenient to use SWAT.

In SWAT, the hydrology of a watershed is simulated under two phases: the land phase and the water (or routing) phase. The land phase controls the amount of water, sediment, nutrient, and pesticide loadings to the main channel in each subwateshed. It is based on the water balance equation:

$$
S W_{t}=S W_{0}+\sum_{i=1}^{t}\left(R_{i}-Q_{i}-E T_{i}-P_{i}-Q R_{i}\right)
$$

where $S W_{t}$ is the final soil water content in $\mathrm{mm}, S W_{0}$ is the initial soil water content available for plant uptake (i.e., initial soil water content minus the permanent wilting point water content) in $\mathrm{mm}, t$ is the time in days, $R_{i}$ is the amount of precipitation in $\mathrm{mm}, Q_{i}$ is the amount of surface runoff in $\mathrm{mm}$, $E T_{i}$ is the amount of evapotranspiration in $\mathrm{mm}, P_{i}$ is the amount of percolation in $\mathrm{mm}$, and $Q R_{i}$ is the amount of return flow in $\mathrm{mm}$.

Using the climatic and vegetation information, which include daily precipitation, maximum/minimum air temperature, solar radiation, wind speed, relative humidity, and leaf area index, SWAT models the daily average soil temperature, evaporation from soils and plants, infiltration, and flow. SWAT offers three options for estimating evapotranspiration: the Hargreaves, Priestly-Taylor, and Penman-Montieth methods. 
In this research, the Penman-Montieth method was used. Percolation is modeled with a layered storage routing technique and a crack flow model.

The surface runoff in each subwatershed or HRU is estimated using the Soil Conservation Service (SCS) curve number method (SCS, 1972):

$Q=\frac{(R-0.2 S)^{2}}{(R+0.8 S)}$

where $Q$ is the daily runoff in mm, $R$ is the daily rainfall in $\mathrm{mm}$, and $S$ is a retention parameter, which varies with soil, land use, slope, and changes in water content and is related to the curve number $(\mathrm{CN})$ :

$S=25.4\left(\frac{1000}{C N}-10\right)$

$\mathrm{CN}$ is the curve number for antecedent moisture condition. Its value for any area can be obtained from the SCS hydrology handbook.

Based on the amount of runoff, sediment yield is estimated using the Modified Universal Soil Loss Equation (MUSLE) from all sources within a subwatershed and simplified sediment transport relations in the channel (Williams, 1975):

$Y=11.8\left(V \cdot q_{p}\right)^{0.56} \cdot K \cdot C \cdot P E \cdot L S \cdot C F R G$

where $Y$ is the sediment yield in metric tons from the subbasin, $V$ is the surface runoff volume, $q_{p}$ is the peak flow rate, $K$ is the soil erodibility factor, $C$ is the crop management factor, $P E$ is the erosion control practice factor, $L S$ is the topographic factor (slope length and steepness), and CFRS is the coarse fragment factor.

Once SWAT determines the loadings of water, sediments, and nutrients in the main channel, the loadings are routed through the stream water. The routing phase is the movement of water, sediments, and nutrients through the channel network to the outlet of the watershed. A simple flood routing method is used within SWAT to route runoff and sediment from both non-point and point sources throughout the watershed, based on the travel time of the flow. The sediment yield predicted by SWAT is comprised of the clay, silt, and fine sand materials eroded from the fields.

SWAT tracks the movement and transformation of several forms of nitrogen. The amount of nitrate lost is a function of the total amount of water leaving the top soil layer and the concentration of nitrate in the top soil layer. The concentration of nitrate can be estimated by dividing the weight of nitrate by the water storage column. Plant use of nitrogen, nitrate, organic nitrogen, as well as plant use of phosphorus, soluble phosphorus, and organic phosphorus are calculated.

In this research, the SWAT model (version 2000) was run through the BASINS interface. Much GIS data layers for
LMR, such as land cover maps from Multi-Resolution Land Consortium (MRLC, from USGS), hydrologic unit code (HUC, from USGS), stream characteristics and Reach File coverages (RF3, from USEPA), digital elevation models (DEMs, from USGS), and soil maps (from STATSGO), at a $30 \times 30 \mathrm{~m}$ cell size are already available in BASINS' meta-database. In addition, information about point source contamination, including those related to waste water treatment plants and industrial discharges, was retrieved from the Permit Compliance System (PCS, from USEPA). Daily climatological data for the climate station at Milford, Ohio, were obtained from the National Climatic Data Center (NCDC). This station locates right at the heart of the LMR valley and has the longest and the most complete climatic record, with only a few missing values. To generate these missing values, the WXGEN weather generator was used (Sharpley and Williams 1990). It is based on a database of weather information on 1,112 stations around the United States. Both the weather generator and the climatic database are provided with the BASINS interface. The climate data together with all other GIS data are used as input into the SWAT hydrologic model.

In the pre-processing, the LMR watershed was delineated into 25 subwatersheds using the automatic delineation tool in BASINS, the DEM grid, and stream characteristics from the RF3 coverage. Parameters for each of the 25 delineated subwatersheds were estimated using the SWAT interface based on the predominant land-use or soil type described by the GIS map layers. Then HRUs were created within each subwatershed wherever a particular land-use type or soil type covered at least 18 to $20 \%$ of the area. Each of these units represents a unique land use/soil combination within the subwatershed. The creation of smaller HRUs within the sub-watershed enables the model to better simulate the differences in evapotranspiration and runoff due to variations in land use and soil conditions, thereby improving the accuracy of the model and providing a better physical description of the water balance. Next, the SWAT hydrological model was executed based on the weather and input databases. Finally, calibration and validation of the hydrological model were performed to ensure the accuracy of the simulation.

The variables chosen for the model calibration and validation are flow, total nitrogen (organic nitrogen and ammonia), total phosphorus, and sediment load. These variables were chosen for a number of reasons. First, these are the basic water quality variables. They can be used to indicate if the model is performing properly. Second, these variables are continuously sampled by the USGS, and sufficient information for model calibration and validation are available.

In addition to visual comparison, a paired t-test was used as a performance criterion to compare the observed data collected from the water monitoring stations with the simulated outputs. It is a useful criterion because it compares each set of data on a daily basis. A t-value of less of 1.0 indicates a statistically significant probability $(\mathrm{p}>0.50)$ that the simulated data is in good agreement with the observed data and the model can be regarded as simulating the real world conditions relatively accurately. Otherwise, the input parameters of the mo- 
del must be adjusted and the model results compared again with the observed data. This procedure was repeated until the simulated data were in close agreement with the observed data.

Once the model has been calibrated, validation was performed to demonstrate that the model was able to portray relatively accurate conditions under a different set of climatic and land use conditions. This step is important to ensure that the calibrated model is capable of functioning accurately under more than one environment, using the same input hydrological parameters as in the calibration. Again, the same performance criterion was used to compare the simulated data with the observed data. If the criterion is met, then the model has been calibrated and validated, and can be expected to produce reliable results. If the performance criterion is not met, then the model needs to be re-calibrated and validated until the performance criterion is met (McCuen and Snyder, 1986).

Table 2. SWAT Model Calibration and Validation Parameters and Results

\begin{tabular}{lll}
\hline \multicolumn{2}{l}{ Calibration/Validation Parameters } & \\
\hline $\begin{array}{l}\text { Channel cover factor } \\
\text { Effective hydraulic conductivity in main } \\
\text { channel alluvium }\end{array}$ & $\begin{array}{l}50 \% \text { variation } \\
\text { SCS runoff curve number for moisture }\end{array}$ & 4 unit variation \\
condition II & \\
Nitrogen percolation coefficient & & 1.0 \\
Phosphorus percolation coefficient & & 17.5 \\
\hline Calibration results & T-value & $\mathrm{P}$ \\
Parameters & 0.23 & $>0.50$ \\
\hline $\begin{array}{ll}\text { Flow } \\
\text { Organic nitrogen + Ammonia }\end{array}$ & 0.63 & $>0.50$ \\
$\begin{array}{l}\text { Total phosphorus } \\
\text { Suspended sediments }\end{array}$ & 0.66 & $>0.50$ \\
\hline Validation results & 0.31 & $>0.50$ \\
Parameters & T-value & $\mathrm{P}$ \\
\hline Flow & 0.19 & $>0.50$ \\
Organic nitrogen + Ammonia & 0.48 & $>0.50$ \\
Total phosphorus & 0.50 & $>0.50$ \\
Suspended sediments & 0.38 & $>0.50$ \\
\hline
\end{tabular}

In this study, the calibration data sets included the 1980s land-use map of the LMR watershed (GIRAS data set from USEPA, 1994) and daily precipitation and temperature data from 1980 to 1989 (from NCDC). The land-use map was reclassified according to the specifications of the SWAT model. The calibration procedure was performed on the hydrology (flow), and nutrient and sediment loadings. Relevant parameters for model calibration included the sensitivity of the model to the different land-use/soil combinations, the curve number in the hydrology component, the effective hydraulic conductivity in the main channel alluvium, the main channel cover factor, and the percolation factors for nitrogen and phosphorus. The calibration was performed by trial-and-error, with each of the above input parameters being adjusted until the simulated results were in close agreement with the observed values. Most of the parameters were adjusted to allow a higher degree of variation in the parameter during model execution. Besides, the nitrogen and phosphorus percolation coefficients were adjusted to reflect the applications of chemicals and fertilizers in the watershed.

Table 2 shows the results of the calibration. All of the values of the simulated parameters were close to the observed values $(\mathrm{P}>0.50)$.

The calibrated parameters were used in the model validation. The validation data sets included the 1990s MRLC land-use map (USGS, 2000b) and daily precipitation and temperature data from 1990 to 1999 (from NCDC). The 1990s land-use data were re-classified according to the speci- fications of the SWAT model.

Table 2 shows the results of the validation. All of the values of the simulated parameters were close to the observed values $(\mathrm{P}>0.50)$. Based on these results, it is evident that the SWAT model is capable of simulating the hydrology and nutrient loadings in the LMR watershed under the current parameterization. Assuming the simulations are realistic, the model is then used to simulate the hydrologic effects of different scenarios of climate change.

\section{Results}

\subsection{Annual Flow}

The response of flow to climate change is in accordance to the increase or decrease in precipitation (Table 3). A comparison between the flow hydrographs and daily precipitation values indicates that the peak flows occurred in the months with the highest rainfalls. With an increase in precipitation by $20 \%$, the annual runoff increases by approximately $35 \%$. Almost the same amount of decrease is observed when the precipitation is decreased by $20 \%$. Similar relationships between precipitation and runoff were also reported (Mimikou and Kouvopoulos, 1991; Miller and Russell, 1992). The increase in temperature does not seem to have much effect on runoff, as seen when comparing the "dry" scenario with the "driest" scenario, or the "wet" scenario with the "wettest" scenario. In these cases, the temperature increases alone have minimal impact when compared to changes in precipitation. This trend has been seen in other studies as well (Chiew et al., 1995; Gellens and Roulin, 1998). Therefore, it suggests that net precipitation, rather than temperature, has a more prominent impact on annual runoff.

\subsection{Annual Nitrogen Load}

The SWAT model simulates the load for four species of nitrogen: nitrate, nitrite, organic nitrogen, and ammonia. In this paper, the results for annual loads and average daily concentrations are shown in Tables 4 and 5, respectively. The results for nitrate and ammonia will be described in detail, because they represent the nitrogen species involved in plant uptake. Also, elevated levels of nitrate and ammonia can lead 
to excessive growth of algae and other aquatic plants. In addition, high nitrate levels can be a health concern to infants, and high levels of ammonia can be toxic to fish (Goudie, 2000).

Table 3. Annual Runoff (in cubic meters per second) for the Base Case Scenario and Four Climate Change Scenarios

\begin{tabular}{ll}
\hline Scenario & Annual Runoff $\left(\mathrm{m}^{3} / \mathrm{s}\right)$ \\
\hline Base Case & 9620 \\
Wettest & $12960(+34.72 \%)$ \\
Wet & $12900(+34.10 \%)$ \\
Dry & $6360(-33.89 \%)$ \\
Driest & $6380(-33.68 \%)$ \\
\hline
\end{tabular}

* Numbers in parentheses indicate percent change from base case scenario

As with the flow data, the highest nitrate loads occur during the wet scenarios, while the lowest loads occur during the dry scenarios (Table 4). The wet scenarios produce approximately a $35 \%$ increase in nitrate load from the base case (from 600 to $800 \mathrm{~g}$ of $\mathrm{N}$ per sq km per day), while the dry scenarios produce a 20 to $40 \%$ decrease in nitrate load (from 600 to $400 \mathrm{~g}$ of $\mathrm{N}$ per sq $\mathrm{km}$ per day). This shows that higher pollutant loads are associated with higher amounts of runoff.

Table 4. Annual Load (in grams of N per square kilometer per day) for the Various Nitrogen Species Modeled in SWAT

\begin{tabular}{lllll}
\hline Scenario & Nitrate & Nitrite & $\begin{array}{l}\text { Organic } \\
\text { Nitrogen }\end{array}$ & Ammonia \\
\hline Base Case & 599 & 100 & 1,718 & 926 \\
Wettest & 798 & 115 & 1,681 & 944 \\
& $(+33.2 \%)$ & $(+14.6 \%)$ & $(-2.1 \%)$ & $(+2.0 \%)$ \\
Wet & 828 & 118 & 1,766 & 883 \\
& $(+38.2 \%)$ & $(+17.7 \%)$ & $(+2.8 \%)$ & $(-4.6 \%)$ \\
Dry & 430 & 98 & 1,364 & 792 \\
& $(-39.4 \%)$ & $(-1.8 \%)$ & $(-20.6 \%)$ & $(-14.5 \%)$ \\
Driest & 462 & 106 & 1,255 & 810 \\
& $(-23.0 \%)$ & $(+6.1 \%)$ & $(-27.0 \%)$ & $(-12.5 \%)$ \\
\hline
\end{tabular}

* Numbers in parentheses indicate percent change from base case scenario

However, when considering average daily concentrations, the lowest concentrations occurred during the wet scenarios, while the highest concentrations occur during the dry scenarios. For nitrate, the dry scenarios produce approximately a 9 to $16 \%$ increase in average daily concentration, while the wet scenarios produce a slight decrease (1 to $3 \%$ ). In almost all species of nitrogen, the average daily concentration increases as the degree of dryness increased. The driest scenario produces the highest nitrate concentration, at $3.77 \mathrm{mg} / \mathrm{L}$. These results indicate that the pollutant is likely to become more concentrated as the runoff volume decreases. This trend also suggests that as our climate changes in the future, the impacts on flow will exceed that on nitrate load.

The average daily concentrations of nitrate range from 3.0 to $4.0 \mathrm{mg} / \mathrm{L}$ for the different scenarios. This concentration is below the EPA's suggested daily limit of $10.0 \mathrm{mg} / \mathrm{L}$ (waters for human consumption; Ohio EPA, 2002).

Nitrate loads vary seasonally, in a fashion similar to that of the flow hydrograph. The highest loads are seen in May and August; and the lowest loads are seen in the preceding months of April and July.

With ammonia, the highest loads occur during the wet scenarios, and the lowest loads occur during the dry scenarios. The wet scenarios result in a $-5 \%$ to $+2 \%$ change in load, while the dry scenarios produce a 13 to $15 \%$ decrease in load (from 926 to $792 \mathrm{~g}$ of $\mathrm{N}$ per sq $\mathrm{km}$ per day; Table 4). The trend is reversed when examining the average daily concentrations, as the highest concentrations are seen in the dry scenarios, and the lowest concentrations are found in the wet scenarios (Table 5).

Table 5. Average Daily Concentration (in $\mathrm{mg} / \mathrm{L}$ ) for the Various Nitrogen Species Modeled in SWAT

\begin{tabular}{lllll}
\hline Scenario & Nitrate & Nitrite & $\begin{array}{l}\text { Organic } \\
\text { Nitrogen }\end{array}$ & Ammonia \\
\hline Base Case & 3.24 & 0.54 & 9.30 & 5.01 \\
Wettest & 3.21 & 0.46 & 6.75 & 3.79 \\
& $(-0.9 \%)$ & $(-14.8 \%)$ & $(-27.4 \%)$ & $(-24.4 \%)$ \\
Wet & 3.34 & 0.47 & 7.13 & 3.56 \\
& $(-3.1 \%)$ & $(-13.0 \%)$ & $(-23.3 \%)$ & $(-28.9 \%)$ \\
Dry & 3.52 & 0.80 & 11.17 & 6.48 \\
& $(+8.6 \%)$ & $(+48.1 \%)$ & $(+20.1 \%)$ & $(+29.3 \%)$ \\
Driest & 3.77 & 0.86 & 10.24 & 6.61 \\
& $(+16.4 \%)$ & $(+59.3 \%)$ & $(+14.1 \%)$ & $(+31.9 \%)$ \\
\hline
\end{tabular}

* Numbers in parentheses indicate percent change from base case scenario

The average daily concentrations of ammonia fall between 4.0 and $7.0 \mathrm{mg} / \mathrm{L}$ for the different scenarios. EPA's ammonia-nitrogen criterion for exceptional warm water habitats is dependent on the $\mathrm{pH}$ and temperature. The maximum limit for ammonia in waters ranging from 0 to $25^{\circ} \mathrm{C}$ in neutral $\mathrm{pH}$ waters is $13.0 \mathrm{mg} / \mathrm{L}$ (Ohio EPA, 2002). In contrast to what one may expect, these results indicate that there does not appear to be an eutrophication problem due to an overabundance of either nitrate or ammonia in the LMR watershed.

As in nitrate, the ammonia-nitrogen loads vary seasonally, with the highest loads occurring in the first six months of the year. The highest peaks occur around mid February, with the exception of the base case scenario, in which the highest peak occurs in August.

\subsection{Annual Phosphorus Load}

The SWAT model simulates the loads of organic phosphorus and mineral phosphorus separately. The results of these two species were summed to derive the load for total phosphorus.

The highest total phosphorus loads occur during the wet scenarios, while the lowest loads occur during the dry scenarios. The wet scenarios produced approximately a 1 to $8 \%$ in- 
crease (from 542 to $585 \mathrm{~g}$ of $\mathrm{P}$ per sq $\mathrm{km}$ per day) in total phosphorus, while the dry scenarios produce approximately a $20 \%$ decrease (from 542 to $434 \mathrm{~g}$ of $\mathrm{P}$ per sq km per day) in total phosphorus (Table 6). When considering average daily concentrations, the lowest concentrations occur during the wet scenarios, while the highest concentrations occur during the dry scenarios. The dry scenarios produce approximately a $20 \%$ increase (from 3.0 to $3.7 \mathrm{mg} / \mathrm{L}$ ) in average daily concentration, while the wet scenarios produce a 22 to $27 \%$ decrease (from 3.0 to $2.2 \mathrm{mg} / \mathrm{L}$; Table 7 ). These trends are similar to the ones found in the nitrogen species.

Table 6. Annual Load (in grams of P per square kilometer per day) for Total Phosphorus

\begin{tabular}{ll}
\hline Scenario & Total Phosphorus \\
\hline Base Case & 542 \\
Wettest & $545(+0.45 \%)$ \\
Wet & $585(+7.87 \%)$ \\
Dry & $450(-17.08 \%)$ \\
Driest & $434(-20.00 \%)$ \\
\hline
\end{tabular}

* Numbers in parentheses indicate percent change from base case scenario

Table 7. Average Daily Concentration (in $\mathrm{mg} / \mathrm{L}$ ) for Total Phosphorus

\begin{tabular}{ll}
\hline Scenario & Total Phosphorus \\
\hline Base Case & 3.00 \\
Wettest & $2.19(-27.00 \%)$ \\
Wet & $2.35(-21.67 \%)$ \\
Dry & $3.68(+22.67 \%)$ \\
Driest & $3.54(+18.00 \%)$ \\
\hline
\end{tabular}

* Numbers in parentheses indicate percent change from base case scenario

The average daily concentration of phosphorus falls in between 2.0 and $4.0 \mathrm{mg} / \mathrm{L}$ for the different scenarios. This concentration is above the EPA's suggested daily limit of 0.1 $\mathrm{mg} / \mathrm{L}$ (for rivers and streams; USEPA, 2002). This indicates that there is more phosphorus in the LMR watershed than can be assimilated by a healthy system, and that eutrophication due to phosphorus is a likely problem.

\subsection{Nitrogen-to-Phosphorus Ratio}

The total nitrogen to total phosphorus ratio ranges from 6.0 to 6.5 for the different scenarios (Table 8). The ratio is lower for the dry scenarios, and higher for the wet scenarios. A ratio less than the recommended 16:1 (for healthy rivers and streams) can mean two things: either a nitrogen deficiency or an overabundance of phosphorus (Horne and Goldman, 1994). Considering the above results that current phosphorus concentrations exceed EPA suggested limits, the total nitrogen to total phosphorus ratio of 6.0 indicates that the system suffers from an overabundance of phosphorus.
Table 8. Total Nitrogen to Total Phosphorus Ratios under Future Climate Change Scenarios

\begin{tabular}{ll}
\hline Scenario & {$[\mathrm{TN}] /[\mathrm{TP}]$} \\
\hline Base Case & 6.03 \\
Wettest & 6.48 \\
Wet & 6.48 \\
Dry & 6.00 \\
Driest & 6.08 \\
\hline
\end{tabular}

\subsection{Annual Sediment Load}

The amount of sediment load under the current conditions is about $4.07 \mathrm{~kg} / \mathrm{sq}^{2} /$ day. Under the wet conditions, the sediment load is higher (about 46\%). Under the dry scenario, the sediment load is lower. The amount of decrease is about $40 \%$ (Table 9 ).

Table 9. Sediment Load (in kg per square kilometer per day) under Future Climate Scenarios

\begin{tabular}{ll}
\hline Scenario & Sediment Load \\
\hline Base Case & 4.07 \\
Wettest & $5.96(+46.47 \%)$ \\
Wet & $5.98(+46.84 \%)$ \\
Dry & $2.38(-41.08 \%)$ \\
Driest & $2.38(-41.08 \%)$ \\
\hline
\end{tabular}

* Numbers in parentheses indicate percent change from base case scenario

\section{Discussion}

Although this study is based on hypothetical scenarios and the results may not reflect what will happen exactly in the future, yet it has shown that the changes in runoff, nutrient, and sediment loads under the simulated climate conditions will be large enough to require a significant planning response. Daily flow increases by $35 \%$ in the wet scenarios, and decreases by a similar amount in the dry scenarios. The changes in flow correspond to the changes in daily precipitation. For most nitrogen species, phosphorus, and sediment load, the dry scenarios produce a higher concentration of pollutants, although the net total amount of pollutant load is less than that during the wet scenarios. This is because, in most cases, the changes in flow are greater than the corresponding change in pollutant load. For instance, during the dry scenarios, the reduction in flow is much greater than the reduction in pollutant load. The opposite is seen in the wet scenarios, where the increase in flow is much greater than the increase in pollutant load.

The changes in nutrient loads, i.e., non-point source pollution, reflect the changes in runoff (Tables 4 and 6). A higher runoff volume would carry increased loads of nutrients, as well as sediments (Table 9). The changes are greater for nitrate, which is increased by 30 to $40 \%$ in response to increases in runoff, than for total phosphorus, which changes by 1 to 
$10 \%$. The average daily concentrations of the nutrients are highest in the dry scenarios, and lowest in the wet scenarios. Also, the results indicate that, under the climate change scenarios, the changes in flow generally exceed the corresponding changes in pollutant load in magnitude. Comparison of the simulated concentrations to EPA's suggested concentrations shows that, while nitrate levels are below the suggested limit $(10 \mathrm{mg} / \mathrm{L})$, phosphorus levels under the climate scenarios exceed the suggested limit $(0.1 \mathrm{mg} / \mathrm{L})$. Together with the nitrogen-to-phosphorus ratios, these findings suggest that the LMR watershed may experience eutrophication due to an overabundance of phosphorus.

Possible sources of excess phosphorus in the LMR include the effluent from wastewater treatment plants (WWTPs) and tributaries that receive agricultural runoff from farmland. Phosphorus is one of the basic components of agricultural fertilizer, and surface runoff can easily transport it from fields to streams that eventually flow into the LMR. Human wastes, dishwasher and dry cleaning detergents, and carpet shampoo also contain high amounts of phosphorus that can pass through WWTPs. While phosphorus removal can be added to treatment facilities relatively easily, it represents a significant operational expense (American Metropolitan Sewerage Association, 2002). If, however, terrestrial sources of phosphorus can be identified, water resource managers can implement cost-effective best management practices (BMP) strategies to curtail its presence in runoff.

In this study, sediment load either increases or decreases by approximately $40 \%$, depending on the scenario. Under the wet scenarios, sediment loadings can exceed $5 \mathrm{~kg}$ per sq $\mathrm{km}$ per day. Since soils in the LMR watershed have high erosion potentials, the non-point source management activities continue to be a pressing concern to water resource managers (Debrewer et al., 2000).

\section{Conclusions}

The simulation of the future climate conditions in the LMR watershed reveals that changes in runoff, nutrient and pollutant loads can range from 1 to $40 \%$. Annual runoff varies according to the precipitation changes in the climate scenarios. Although a high runoff volume and an increased pollutant load are usually associated with high precipitation events, there also appears to be a decrease in pollutant concentration as runoff increases.

Based on these results, it seems that climate change will have significant impacts on surface-water runoff. In many cases, these impacts are compounded by the inadequacies of our current water treatment systems to cope with climatic anomalies. This can translate into reduced water supply to our drinking water and wastewater treatment facilities. Furthermore, extreme high temperatures and low levels of precipitation can result in low flow conditions in rivers and streams, which, in turn, contribute to the toxic concentration of pollutants, such as algae, minerals, and water-bourne pathogens.

According to the simulation results, the LMR watershed does not experience eutrophication from an overabundance of nitrogen (as seen in other studies), but an overabundance of phosphorous. The eutrophication problem in the LMR watershed can be exacerbated in future climate conditions. As a consequence, these forecasted climate changes may have long-range impacts on the health and integrity of the LMR's aquatic ecosystem. Moreover, as the LMR watershed continues to urbanize in the next few decades, the changes in landuse patterns in the watershed may further exemplify the effects of climate change on water quality.

Acknowledgments. We would like to thank J. Arnold of USDA Agricultural Research Service for the use of the SWAT model and the USEPA for the BASINS databases. We also thank S. Gutierrez and J. Neal of the National Risk Management Research Laboratory of the USEPA for their helpful assistance.

\section{References}

Alexander, R.B., Smith, R.A., Schwarz, G.E., Preston, S.D., Brakebill, J.W., Srinivasan, R. and Pacheco, P.A. (2001). Atmospheric nitrogen flux from the watersheds of major estuaries of the United States: An application of the SPARROW watershed model, in R. Valigura, R. Alexander, M. Castro, T. Meyers, H. Paerl, P. Stacey and R.E. Turner (Eds.), Nitrogen Loading in Coastal Water Bodies: An Atmospheric Perspective. Am. Geophys. Union Monograph, 57, 119-170.

American Metropolitan Sewerage Association (2002). Communities at Work: The National Response to Combined Sewer Overflows Report, American Metropolitan Sewerage Association, Washington, DC, USA.

Arnold. J.G. and Fohrer, N. (2005). SWAT 2000: Current capabilities and research opportunities in applied watershed modeling. $H y$ drol. Process., 19, 563-572.

Arnold, J.G., Williams, J.R., Srinivasan, R., King, K.W. and Griggs, R.H. (1994). SWAT-Soil and Water Assessment Tool-User Manual, Agriculture Research Service, Grassland, Soil and Water Research Lab, US Department of Agriculture.

Bhaduri, B., Grove, M., Lowry, C. and Harbor, J. (1997). Assessing long-term hydrologic effects of land use change. J. Am. Water Works Assoc., 89(11), 94-106

Bicknell, B.R., Imhoff, J.C., Kittle, J.L.Jr., Dionigian, A.S.Jr. and Johanson, R.C. (1997). Hydrological Simulation ProgramFortran User's Manual for Release 11, US Environmental Protection Agency, Environmental Research Laboratory, Athens, Georgia, USA, EPA/600/R/97/080.

Bingner, R.L., Murphree, C.E. and. Mutchler, C.K. (1989). Comparison of sediment yield models on various watersheds in Mississippi. Trans. Am. Soc. Agric. Eng., 23, 529-534.

Bingner, R.L., Garbrecht, J., Arnold, J.G. and Srinivasan, R. (1997). Effect of watershed subdivision on simulation runoff and fine sediment yields. Trans. Am. Soc. Agric. Eng., 40, 1329-1335.

Bonsal, B.R., Prowse, T.D. and Pietroniro, A. (2003). An assessment of global climate model-simulated climate for the western cordillera of Canada (1961-90). Hydrol. Process., 17(18), 37033716.

Burkart, M. and James, D.E. (1999). Agriculture-nitrogen contribution to hypoxia in the Gulf of Mexico. J. Environ. Qual., 28(3), 850-859.

Caraco, N.F. and Cole, J.J. (1999). Human impact on nitrate export: An analysis using major world rivers. Ambio., 28, 167-170.

Chang, H., Knight, C.G., Staneva, M.P. and Kostov, D. (2002). Water resource impacts of climate change in southwestern Bulgaria. GeoJ., 57(3), 159-168.

Chaplot, V., Saleh, A., Jaynes, D.B. and Arnold, J. (2004). Predicting 
water, sediment and $\mathrm{NO}_{3}-\mathrm{N}$ loads under scenarios of land-use and management practices in flat watershed. Water, Air, Soil Pollut., 154, 271-293.

Chiew, F.H.S., Whetton, P.H., McMahon, T.A. and. Pittock, A.B. (1995). Simulation of the impacts of climate change on runoff and soil moisture in Australian catchments. J. Hydrol., 167, 121-147.

Cho, S.M., Jennings, G.D., Stallings, C. and Devine, H.A. (1995). GIS-based Water Quality Model Calibration in the Delaware River Basin, ASAE Microfiche No. 952404, ASAE, St. Joseph, Michigan.

Coe, M.T. (1998). A linked global model of terrestrial hydrologic processes: Simulation of modern rivers, lakes, and wetlands. $J$. Geogr. Res., 103(D8), 8885-8899.

Cooter, E.J. and Cooter, W.S. (1990). Impacts of greenhouse warming on water temperature and water quality in the southern United States. Clim. Res., 1, 1-12.

Crawford, H.S. and Jennings, J.Y. (1989). Predation of birds on spruce budworm Choristoneura fumiferana: Functional, numerical, and total responses. Ecol., 70, 152-163.

Dagnachew, L., Vallet-Coulomb, C. and Gasse, F. (2003). Hydrological response of a catchment to climate and land use changes in tropical Africa: Case study of south central Ethiopia. J. Hydrol., 275(1-2), 67-85.

Debrewer, L.M., Rowe, G.L., Reuter, D.C., Moore, R.C., Hambrook, J.A. and Baker, N.T. (2000). Environmental Setting and Effects on Water Quality in the Great and Little Miami River Basins, Ohio and Indiana, National Water-Quality Assessment Program Water-Resources Investigations Report 9-2401.

Dettinger, M.D., Cayan, D.R., Meyer, M.K. and Jeton, A.E. (2004). Simulated hydrologic responses to climate variations and change in the Merced, Carson, and American River Basins, Sierra Nevada, California, 1900-2099. Clim. Change, 62(1-3), 283-317.

Donner, S.D., Coe, M.T., Lenters, J.D., Twine, T.E. and Foley, J.A. (2002). Modeling the impact of hydrological changes on nitrate transport in the Mississippi River Basin from 1955 to 1994 Global Biogeochem. Cycles, 16, 1043.

Donner, S.D. and Kucharik, C.J. (2003). Evaluating the impacts of land management and climate variability on crop production and nitrate export across the Upper Mississippi Basin. Global Biogoechem. Cycles, 17(3), 1085.

Flaschka, I., Stockton, C.W. and Boggess, W.R. (1987). Climatic variation and surface water resources in the Great Basin region. Water Resour. Bull., 23, 47-57.

Gellens, D. and Roulin, E. (1998). Streamflow response of Belgian catchments to IPCC climate change scenarios. J. Hydrol., 210, 242-258.

Gleick, P.H. (1987). The development and testing of a water balance model for climate impact assessment: Modeling the Sacramento Basin. Water Resour. Res., 23(6), 1049-1061.

Goudie, A. (2000). The Human Impact on the Natural Environment, the MIT Press, Cambridge, Massachusetts.

Grizzetti, B., Bouraoui, F., Granlund, K., Rekolainen, S. and Bidoglio, G. (2003). Modelling diffuse emission and retention of nutrients in a Vantaanjoki watershed (Finland) using the SWAT model. Ecol. Model., 169(1), 25-38.

Henratty, M.P. and Stefan, H.G. (1998). Simulating climate change effects in a Minnesota agricultural watershed. J. Environ. Qual., $27,1524-1532$

Horne, A.J. and Goldman, C.R. (1994). Limnology, McGraw-Hill, Toronto.

Howarth, R.W., Billien, G., Swaney, D., Townsend, A., Jaworski, N., Lajtha, K., Downing, J.A., Elmgren, R.E., Caraco, N., Jordan, T., Berendse, F., Freney, J., Kudeyarov, V., Murdoch, P. and Zhu, X.L. (1996). Regional nitrogen budgets and riverine $\mathrm{N}$ and $\mathrm{P}$ fluxes for the drainages to the North Atlantic Ocean: Natural and human influences. Biogeochem., 35, 75-139.

IPCC (2001). Climate Change 2001: The Scientific Basis. Contribution of Working Group I to the Third Assessment Report, Cambridge University Press, Cambridge, UK.

IPCC (2004). Third Assessment Report. United States, Congress, Senate, Committee on Commerce, Science, and Transportation.

Jayakrishnan, R., Srinivasan, R., Santhi, C. and Arnold, J.G. (2005). Advances in the application of the SWAT model for water resources management. Hydrol. Process., 19, 749-762.

Johnes, P.J. and Hearthwaite, A.L. (1997). Modelling the impacts of land use change on water quality in agricultural catchments. $\mathrm{Hy}$ drol. Process., 11, 269-286.

Justic, D., Turner, R.E. and Rabalais, N.N. (2003). Climatic influences on riverine nitrate flux: Implications for coastal marine eutrophication and hypoxia. Estuaries, 26(1), 1-11.

Karl, T.R. (1992). Contemporary global warming: Are we sure? in S.K. Majumdar, L.S. Kalkstein, B. Yarnal, E.W. Miller and L.M. Rosenfeld (Eds.), Global Climate Change: Implications, Challenges, and Mitigation Measures, The Pennsylvania Academy of Science, pp. 37-49.

Karl, T.R., Knight, R.W., Easterling, D.R. and Quayle, R.Q. (1996). Indices of climate change for the United States. Bull. Am. Meteorol. Soc., 77, 279-292.

Lerch, N.K., Hale, W.F. and Milliron, E.L. (1975). Soil Survey of Clermont County, Ohio Department of Agriculture.

Lettenmaier, D.P. and Gan, T.Y. (1990). Hydrologic sensitivities of the Sacramento-San Joaquin River Basin, California to global warming. Water Resour. Res., 26, 69-86.

Liu, A.J., Tong, S.T.Y. and Goodrich, J.A. (2000). Land use as a mitigation strategy for the water-quality impacts of global warming: A scenario analysis on two watersheds in the Ohio River Basin. Environ. Eng. Policy, 2, 65-76.

McCuen, R.H. and Snyder, W.M. (1986). Hydrological Modelling: Statistical Methods and Applications, Prentice-Hall, New Jersey.

Miller, J.R. and Russell, G.L. (1992). The impact of global warming on river runoff. J. Geophys. Res., 97, 2757-2764.

Mimikou, M. and Kouvopoulos, Y.K. (1991). Regional climate change impacts, 1: Impacts on water resources. Hydrol. Sci. J., 36, 247-258.

Najiar, R.G. (1999). The water balance of the Susquehanna River Basin and its response to climate change. J. Hydrol., 219, 7-19.

Nash, L.L. and Gleick, P.H. (1991). Sensitivity to streamflow in the Colorado Basin to climatic changes. J. Hydrol., 125, 221-241.

Neitsch, S.L., Arnold, J.G., Kiniry, J.R., Srinivasan R. and Williams, J.R. (2002). Soil and Water Assessment Tool User's Manual Version 2000, Report 02-02, BRC report 02-01, Grassland, Soil, and Water Research Laboratory, Texas Water Resources Institute TR-192, Agricultural Research Services, Texas.

ODNR (1964). Water Inventory of the Little Miami and Mill Creek Basins and Adjacent Ohio River Tributaries, Report 18, Ohio Water Plan Inventory.

Ohio EPA (1995). Biological and Water Quality Study of the Little Miami River and Selected Tributaries, Ohio Environmental Protection Agency Technical Report Number MAS/1994-12-11, Ohio EPA Division of Surface Water.

Ohio EPA (2000). Biological and Water Quality Study of the Little Miami River Basin, 1998, Ohio Environmental Protection Agency Technical Report Number MAS/1999-12-3, Ohio EPA Division of Surface Water.

Ohio EPA (2002). Ohio Administrative Code-Chapter 3745-1 Water Quality Standards, Division of Surface Water.

Perry, S. (Ed.) (1989). Nonpoint Source Pollution: Land Use and Water Quality, Washington County Project.

Peterson, J.R. and Hamlett, J.M. (1998). Hydrologic calibration of the SWAT model in a watershed containing fragpan soils. J. Am. 
Water Resour. Assoc., 34(3), 531-544.

Ranjan, M.S. and Wurbs, R.A. (2002). Scale-dependent soil and climate variability effects on watershed water balance of the SWAT model. J. Hydrol., 256(3-4), 264-285.

Romanowicz, A.A., Vanclooster, M., Rounsevell, M. and La Junesse, I. (2005). Sensitivity of the SWAT model to the soil and land use data parametrisation: A Case study in the Thyle catchment, Belgium. Ecol. Model., 187, 27-39.

Sharpley, A.N. and Williams, J.R. (Eds.) (1990). EPIC-Erosion Productivity Impact Calculation I: Model Documentation, Agricultural Research Service, Tech Bulletin 1768, US Department of Agriculture.

Sophocleous, M.A., Koelliker, J.K., Govindaraju, R.S., Birdie, T.S., Ramireddygari, R. and Perkins, S.P. (1999). Integrated numerical modeling for basin-wide water management: The case of the Rattlesnake Creek basin in south-central Kansas. J. Hydrol., 241, 179196.

Srinivasan, R., Arnold, J.G., Muttiah, R.S., Walker, D. and Dyke, P.T. (1993). Hydrologic unit modeling of the United States (HUMUS), in S. Yan (Ed.), Advances in Hydro-Science and Engineering, Washington, DC, 1, Part A, pp. 451-456.

Thompson, S.A. (1992). Simulation of climate change impacts on water balances in the central United States. Phys. Geogr., 13, 31-52.

Tripathi, M.P., Panda, R.K. and Raghuwanshi, N.S. (2005). Development of effective management plans for critical subwatersheds using SWAT model. Hydrol. Process., 19(3), 809-826.

Tong, S.T.Y. and Chen, W. (2002). Modeling the relationship between land use and surface water quality. J. Environ. Manage., 66, 377-393.

SCS (1972). National Engineering Handbook, Hydrology, Section 4, Chapters 4-10, Soil Conservation Service, US Department of Agriculture.

USEPA (1994). 1:250,000 Scale Quadrangles of Landuse/landcover
GIRAS Spatial Data in the Conterminous United States, Office of Information Resources Management.

USEPA (1998). Climate Change and Ohio, Office of Policy, EPA236-F-98-007s.

USEPA (2002). Summary Table for the Nutrient Criteria Documents, Office of Water, Washington, DC. http://www.epa.gov/waterscie nce/criteria/nutrient/ecoregions/sumtable.pdf.

US Forest Service and National Park Service (1999). The Wild and Scenic River Study Process, Technical Report Prepared for the Interagency Wild and Scenic Rivers Coordinating Council, Oregon.

USGS (2000a). Environmental Setting and Effects on Water Quality in the Great and Little Miami River Basins, Ohio and Indiana, Water-Resources Investigations Report 99-4201, National Water-Quality Assessment Program.

USGS (2000b). Ohio National Land Cover Data, Multi-resolution Land Characterizaton Consortium, EROS Data Center.

USGCRP (2000). Climate Change Impacts on the United States: The Potential Consequences of Climate Variability and Change, National Assessment Synthesis Team.

Whitehead, P.G., Wilson, E.J. and Butterfield, D. (1998). A semi-distributed integrated nitrogen model for multiple source assessment in catchments (INCA): Part 1-Model structure and process equations. Sci. Total Environ., 210/211, 547-558.

Williams, J.R. (1975). Sediment-yield prediction with universal equation using runoff energy factor. Present and Prospective Technology for Prediction Sediment Yield and Sources, in Proc. of the Sediment Yield Workshop, US Department of Agriculture Sedimentation Lab, Oxford, November 28-30, 1972, MS ARS-S-40, pp. 244-252.

Young, R.A., Onstad, C.A. and Bosch D.D. (1995). AGNPS: An agricultural nonpoint source model, in V.P. Singh (Ed.) Computer Models of Watershed Hydrology, Water Resources Publications, Colorado. 